\title{
ROZWAŻANIA O „DOBRYM” I „ZŁYM” WYCHOWANIU
}

Streszczenie: W zaprezentowanym artykule autorka prowadzi rozważania dotyczące istoty i zadań współczesnego wychowania. Traktuje je jako powinność dorosłych wobec młodych. Jest to również zadanie, którego nie powinno się nigdy zaniedbywać. Autorka stara się uzasadnić pogląd, że wychowanie nie powinno być też nigdy „złe”. W jej przekonaniu mogą zdarzyć się niewłaściwe zachowania i postawy dorosłych wobec młodych ludzi, lecz wychowanie, w którym wychowawca winien kierować się intencją czynienia dobra i obdarowywać nim dziecko, powinno być zawsze dobre. W świetle zaprezentowanego piśmiennictwa i własnych refleksji autorka stara się omówić i uzasadnić tak sformułowaną tezę.

Słowa kluczowe: wychowanie, dziecko, wychowawca, rodzice, wartości, relacja wychowawcza.

Dziecko to jak dobrze wypolerowane lustro, na którym znać każde nasze dotknięcie

W. Brejnak

\section{Wychowanie jako powinność i dar dla dziecka}

Wychowanie zawsze było i ciągle jest powinnością dorosłych wobec młodych. Należałoby je nawet traktować jako obowiązek, który ma polegać na wprowadzaniu dziecka w świat, który ono ma stopniowo poznawać, nabywając w ten sposób umiejętności rozumienia otaczającej go rzeczywistości i swojego w niej miejsca, roli i znaczenia. Wychowanie jest też prawem każdego dziecka, i dorośli są zobowiązani to prawo respektować. A zatem należy traktować wychowanie - z jednej strony - jako obowiązek dorosłych wobec dziecka, a zarazem prawo tego drugiego, ponieważ „Człowiek jest istotą wymagającą wychowania. Młody człowiek potrzebuje pomocnych wskazówek, koniecznych dla zorientowania go w sposobach istnienia, charakterystycznych dla społeczeństwa, w jakim żyje. [...] Odmówić dziecku wychowania byłoby rzeczą bezlitosną i nieodpowiedzialną, gdyż wtedy dziecko musiałoby żyć w całkowicie nieznanym sobie świecie” (Schwengeler 1990, s. 7). 
Takie wychowanie, w którym dziecku ujawnia się i uzasadnia obecne w otaczającym go świecie wartości i zachęca się je do życia zgodnie z ich wymaganiami, jest darem, którym wychowawca obdarza wychowanka. Tym samym staje się ono wsparciem i pomocą dla dziecka na drodze jego dorastania do człowieczeństwa, a jednocześnie impulsem do harmonijnego i wszechstronnego rozwoju młodej osobowości. A chodzi o to, aby żadnej ze sfer osobowości w wychowaniu nie pominąć lub nie zaniedbać. Z jednakową starannością traktować winno się rozwój intelektualny dziecka, jak i moralno-społeczny, estetyczny, fizyczny, zdrowotny i duchowy. Zatem takie pojmowanie istoty wychowania prowadzi do konkluzji, że jest ono okolicznością, w której działanie wychowawcy charakteryzuje intencja czynienia dobra wobec wychowanka. W ten sposób wychowawcę w postępowaniu z wychowankiem powinien charakteryzować świadomy zamiar, ukierunkowany na odkrywanie pokładów dobra w dziecku, wydobywanie ich i ukazywanie ich wychowankowi. A wszystko po to, aby dziecko stopniowo nabywało skłonności do kierowania się dobrem - zarówno własnym, jak i innych - w trakcie podejmowania jakichkolwiek decyzji czy dokonywania wyborów. Podobnie rzecz ujmuje Maria Łopatkowa, pisząc, że „bez względu na to, czy w naturze ludzkiej dobro jest skłonnością wrodzoną, a zło nabytą, czy tkwią w nas oba wrodzone zalążki dobra i zła - dobro dzięki wychowaniu może dominować nad złem" (Łopatkowa 1992, s. 12).

Prawdą jest, że prawdziwym wychowawcą jest ten, kto pragnie dla dziecka dobra, a więc ten, kto jest zdolny je kochać. Chodzi oczywiście o miłość rozumną, czyli taką, która „sprzyja jego (dziecka - przyp. aut.) psychicznemu rozwojowi, jest niezbędna do kształtowania w ludzkiej istocie kultury uczuć, budzi zaufanie i przywiązanie" (Szlązakowa 1989, s. 158). Miłość wychowawcy do dziecka nie wyraża się bynajmniej w tym, że w imię tej miłości ma ono wszystko otrzymać, że trzeba mu na wszystko pozwolić, jednocześnie niczego od niego nie wymagając. Przed postawą miłości pozornej, która jest daleka od postawy miłości racjonalnej, ostrzegają same dzieci w kierowanym do rodziców i wychowawców Apelu Twojego Dziecka1, wówczas, gdy proszą: „Nie psuj mnie, dając mi wszystko, o co cię poproszę. Niektórymi prośbami jedynie wystawiam cię na próbę" (Apel Twojego Dziecka, s. 1).

W zdefiniowaniu tego, czym jest miłość rozumna, bardzo pomocna jest postawa Janusza Korczaka wobec dzieci, jak i analiza jego pedagogicznej twórczości, która wskazuje na to, że jest „to postawa bezinteresownej życzliwości dla każdego dziecka, chęć jak najbardziej wnikliwego rozpoznania jego potrzeb i gotowość do

1 Apel Twojego Dziecka został zainspirowany analizą tekstów i wypowiedzi Janusza Korczaka, ale on sam nie jest jego autorem. W Polsce tekst Apelu został opublikowany w latach 8o. XX wieku jako tłumaczenie broszury przywiezionej przez prof. Czesława Walesę z USA. W latach 90. XX wieku własną wersję ulotki opracowała i opublikowała Fundacja „Dzieci Niczyje” (dzisiaj: Fundacja „Dajemy Dzieciom Siłę”). 
ich zaspokajania. To prawdziwa troska o los dziecka. W jego wysiłku poznawania praw życia to pomocna dłoń dorosłego doświadczenia, której z pełnym zaufaniem powierzy swoja rączkę dziecko. To postawa wiernej przyjaźni [...]” (za: Szlązakowa 1989, s. 158). Trzeba pamiętać o tym, że tylko w sytuacji, gdy okazujemy dziecku swoją życzliwość, zrozumienie, uwagę możemy oczekiwać, iż odpowie ono na taką postawę sympatią i zaufaniem, będzie mogło czuć się bezpiecznie i zechce być blisko takiego wychowawcy (Zarzecki 2012).

Okoliczność, w której odbywa się wychowanie nierzadko nazywa się spotkaniem - wychowawcy z wychowankiem, dorosłego z młodym, rodzica z dzieckiem. Będzie to spotkanie wzbogacające obydwa podmioty tylko wówczas, jeśli „jako wynik przynosi ono nie tylko jakąś zmianę (w osobowości spotykających się przyp. aut.), ale osobowość zostaje gruntownie przeobrażona; wpływ spotkania jest wówczas dogłębny i długotrwały” (Tarnowski 1990, s. 155). Jeśli więc wychowanie ma być spotkaniem, to powinno się w nim znaleźć miejsce na „bycie ze sobą”, a nie może być mowy o „byciu obok siebie”. Nie jest bowiem możliwe spotkanie w sytuacji, gdy będziemy do siebie odwróceni plecami. W takim przypadku każda z osób dostrzega przed sobą inny obraz, inny horyzont, inną rzeczywistość, w której nie można ujrzeć tej drugiej osoby, gdyż jest właśnie do niej odwrócona plecami. Nie można jej usłyszeć, ponieważ jej głos biegnie w przeciwnym kierunku. Nie można jej zakomunikować żadnego uczucia z powodu zwrócenia się plecami do niej; nie istnieje też wówczas szansa, aby poznać i przyjąć emocje, którymi ta osoba chce nas obdarzyć, jak również nie ma możliwości okazania jej własnych uczuć. Po to, żeby „być” z drugim człowiekiem, trzeba chcieć się ku niemu zwrócić, skupić na nim całą swoją uwagę, poświęcić mu czas, wsłuchać się w to, co i jak mówi, chcieć zrozumieć, co i dlaczego chce zakomunikować. Jest to postawa szczególnie pożądana w sytuacji wychowawczej, jeśli zależy nam na tym, aby proces wychowania rzeczywiście zaistniał. Przyczyny wychowawczego niepowodzenia upatruje się bowiem najczęściej w sytuacji, gdy wychowawca dystansuje się wobec wychowanka i w związku z tym nie ma możliwości okazania mu swojej miłości, w gestach czy słowach, nawet wtedy, gdy rzeczywiście go kocha (Cian 1991). Zachowując dystans w relacji z wychowankiem, trudno jest mu zatem zaoferować wychowanie.

$\mathrm{W}$ procesie wychowania, traktowanym jako spotkanie, nie da się postawić znaku równości pomiędzy „być z kimś” i „mieć kogoś”. Bycie z dzieckiem wymaga od rodzica albo wychowawcy podejścia dialogicznego, czyli podmiotowego, podczas gdy to drugie odniesienie, czyli „mieć”, określa raczej podejście przedmiotowe, instrumentalne. Jest to taki sposób traktowania wychowanków, który zezwala na „stosowanie wobec nich w nadmiarze przymusu zewnętrznego. Polega ono na traktowaniu wychowanków wyłącznie jako rodzaj tworzywa, wymagającego przetworzenia za pomocą z góry zaprogramowanych oddziaływań z zewnątrz" (Łobocki 2004, s. 148). Z przedmiotem można zrobić to, co tylko się komuś podoba. Nie trzeba się z nim liczyć, można go lekceważyć, nie obdarzać uwagą. Jeśli więc dziecko ma być podmiotem wychowania, to wychowawca musi być gotowy na spotkanie 
i bycie z nim. Będzie się to wyrażać w szacunku dorosłego wobec dziecka i uznaniu jego prawa do „niezależności (autonomii) i odrębności (niepowtarzalności). Nie oznacza to oczywiście, że wolno im (dzieciom - przyp. aut.) postępować zawsze wedle własnego uznania, że mogą pozwalać sobie na wszystko. Taka sytuacja byłaby pedagogicznie zgubna (...) prowadziłaby do ogólnej dezorientacji wychowanków w kwestii odróżniania dobra od zła" (Łobocki 2004, s. 147).

$\mathrm{W}$ podmiotowo zabarwionym spotkaniu z dzieckiem, w procesie jego wychowania, nie wystarczy bynajmniej jedynie obiektywna obserwacja zachowań i poczynań dziecka, nawet gdyby miała być ona bardzo wnikliwa i ustawiczna, „tu trzeba współodczuwania, identyfikowania się z pragnieniami dziecka i zdobycia jego zaufania. Trzeba osobistego zaangażowania - jak Korczak, który z dziećmi po dziecięcemu cieszył się i smucił, dostosowywał do toku ich rozumowania i języka wypowiedzi" (Szlązakowa 1989, s. 156). Takie wychowanie można nazwać towarzyszeniem dziecku na drodze jego rozwoju. Wychowawca, który tak postępuje, jest autentycznym towarzyszem i przyjacielem dziecka, zawsze gotowym obdarować je pomocą, a łącząca ich relacja jest „altruistyczną, a nade wszystko kooperacyjną” (Łobocki 2004, s. 148). Tylko w takim przypadku ,szkoła (ale też dom i każde inne środowisko wychowawcze - przyp. aut.) nie będzie miejscem nadmiaru monologu i pouczeń nauczycieli (i rodziców - przyp. aut.), lecz miejscem ich współdziałania i współpracy z uczniami (dziećmi, wychowankami - przyp. aut.)" (Łobocki 2004, s. 148).

\section{Czym jest wychowanie, a co wychowaniem nie jest?}

W piśmiennictwie pedagogicznym nie występuje jedna tylko definicja wychowania, lecz jest ich wiele. Sposób określania pojęcia „wychowanie” reprezentuje zwykle podejście autora do istoty zjawiska i jednocześnie określa jego stanowisko wobec pojmowania w nim miejsca i roli wychowawcy, jak również wychowanka.

Przekonującą może być matafora, którą stosuje w swojej wypowiedzi na temat istoty wychowania Wojciech Brejnak. Powiada on mianowicie tak: „Gdyby człowieka porównać do drzewa, to wczesne dzieciństwo zaczyna się od rozwoju korzeni, z których wyrasta pień z konarami. Jeśli popełnia się błędy na etapie wzrastania, czyli na etapie korzeni, to mimo wyrastania ze zdrowego nasienia, jego pień i konary mogą być zdeformowane. Dlatego wychowanie dziecka powinno być już od najmłodszych lat wychowaniem rozumnym, czyli takim działaniem, w którym po sformułowaniu podstawowych, racjonalnych celów poszukuje się optymalnych środków (sposobów) ich realizacji" (Brejnak 1993, s. 5).

Rozumne wychowywanie młodych wymaga tego, aby rozbudzać ich świadomość i wiedzę na temat tego, co to znaczy stawać się osobą, aktywnie włączać ich do pracy nad własnym rozwojem, pobudzać ich do odpowiedzialności. Takie podejście jest bliskie wielu pedagogom prezentującym personalistyczne odniesienie do wychowania. Jednym z nich był salezjanin, św. Jan Bosko (1815-1888), który budował 
i rozwijał swoje podejście do wychowania dzieci i młodzieży nie tyle w oparciu o studia nad literaturą, ile poprzez czerpanie doświadczenia $\mathrm{z}$ bezpośredniego obcowania z dziećmi i młodzieżą. Obserwując młodych, którzy wkraczali na drogę przestępstwa, dostawali się do więzień, a także po odbyciu kary często ponownie trafiali w to samo miejsce, rozumiał, co było tego powodem. Tym dzieciom zabrakło miłości dorosłych, zostały zostawione same sobie, rodzice nie okazali im należnej troski ani nie otoczyli opieką (Bilicki 200o). Dlatego, kiedy J. Bosko stara się wyjaśnić, czym jest wychowanie, to powiada, że jest ono „(...) sprawą serca. Ten, kto wie, że jest kochany, sam też kocha. Ten, kto jest kochany, osiąga wszystko, zwłaszcza z młodzieżą. A kiedy miłość blednie, wszystko przestaje się układać" (za: Cian, 1991, s. 152). Dlatego wychowanie prewencyjne, bo tak właśnie nazywa się metodę wychowawczą Jana Bosko, stara się jednoznacznie określić wymagania dla wychowawcy, którego „zadaniem (...) miało być tzw. asystenctwo, czyli konstruktywne towarzyszenie podopiecznemu i wzmacnianie jego samoodpowiedzialności” (Bilicki 2000, s. 35).

W podobny sposób konkluduje refleksje Janusza Korczaka dotyczące dzieci sprawiających trudności wychowawcze i występnych A. Szlązakowa. Autorka pisze: „Według Korczaka dziecko występne to dziecko chore, okaleczone psychicznie, dziecko, któremu w życiu zabrakło miłości" (Szlązakowa 1989, s. 159). A więc idąc dalej tym tokiem rozumowania, można powiedzieć, że to takie dziecko, któremu dorośli - rodzice i wychowawcy - odmówili prawa do wychowania. W ich życiu było ono nieobecne, gdyż obowiązek wychowania dziecka został zaniedbany.

Brakuje wychowania tam, gdzie młodym nie stworzono możliwości zapoznania się z podstawowymi wartościami wyznaczającymi zakres i ramy człowieczeństwa i przyswojenia ich sobie. Nie ma wychowania, w moim przekonaniu, w takiej sytuacji, kiedy została zerwana więź i relacja pomiędzy dorosłym a młodym człowiekiem, wszak wychowanie zawsze cechuje się relacyjnością, czyli wzajemnym odniesieniem, więzią, która obie osoby ubogaca i rozwija. Budowanie i utrzymywanie więzi $\mathrm{z}$ wychowankiem powinno być niezbędnym zabiegiem i wyrazem "pewnego sposobu bycia i postawy, skoncentrowanej na rozwijającej się jednostce i na więzi interpersonalnej, na wysokich wartościach, które należy proponować oraz wspólnie (z wychowankiem - przyp. aut.) poszukiwać i realizować" (Cian 1991, s. 93). Taka bliska więź w sposób szczególny wzbogaca dziecko, rozwija w nim to, co nazywamy pierwiastkiem człowieczeństwa. Natomiast bywa i tak, że niekiedy ta więź, która powinna łączyć wychowawcę z wychowankiem, zostanie zerwana, albo też nie dochodzi do nawiązania interakcji wychowawczej. Antonina Gurycka (1990) nazywa taką sytuację wprawdzie nie brakiem wychowania, ale raczej błędami w wychowaniu, co oczywiście daje się uzasadnić. Rzeczywiście, jest to błąd popełniany przez wychowawcę, który - jak powiedziano powyżej - jest zobowiązany do wychowania, a zatem jeśli zrywa relację z wychowankiem lub w ogóle decyduje się jej nie nawiązywać, to popełnia błąd wychowawczy. Ale z drugiej strony, jeśli interakcja między wychowawcą i wychowankiem już nie występuje, oczywiste 
jest, że także nie ma między nimi tego, co nazywamy wychowaniem. Można taką okoliczność traktować więc zarówno jako błąd (zaniechanie obowiązku wobec młodego człowieka), jak i brak wychowania.

Sytuację, w której zabrakło wychowania, w przekonujący sposób objaśnia Janusz Tarnowski, kiedy odwołuje się do pewnego zdarzenia sprzed lat. Warto je w tym miejscu przywołać i opowiedzieć słowami autora. Ksiądz J. Tarnowski wspomina: „Przed laty spędzałem wakacje w pewnej malowniczej wiosce niedaleko Zakopanego. Dzieci przebywające tam na kolonii urządziły ognisko dla miejscowej ludności i wczasowiczów. Spotkała mnie miła niespodzianka. Oto siedząc wraz z innymi dookoła ogniska, rozpoznałem wśród wychowawców kolonijnych swoich dwóch dawnych uczniów. Po spotkaniu zapytałem, jak wygląda ich praca wychowawcza.

- Wcale nie wygląda - usłyszałem w odpowiedzi. My tylko pilnujemy, aby dzieci sobie «głów nie pourywały». Nawet nie próbujemy ich wychowywać. Od tego jest dom i szkoła.

A zatem moi dawni uczniowie byli wychowawcami tylko z nazwy. Trudno ich chyba za to pochwalić. Dobrze jednak, że zdawali sobie przynajmniej sprawę ze swej właściwej roli” (Tarnowski 1993, s. 11).

Przywołane wspomnienie nawet nie wymaga specjalnego komentarza. W tym zdarzeniu mamy do czynienia z sytuacją zerwanych więzi i bliskości, nie ma w niej miejsca na „bycie ze sobą”, jest tylko „bycie obok siebie”, często - jak można przypuszczać - z odwracaniem się do wychowanka i jego potrzeb plecami.

Podzielam ponadto pogląd J. Tarnowskiego, który przekonuje, że nie można nazywać wychowaniem takiej okoliczności, w której wychowankowi wyznacza się rolę biernego przedmiotu, degraduje się niejako jego wartość jako osoby. Takie oddziaływanie nie ma jednak charakteru pedagogicznego. Nie powinno się zatem utożsamiać z wychowaniem pewnego rodzaju oddziaływania na dziecko, jak np. tresura, administrowanie, trening, moralizowanie czy kształtowanie osobowości (Tarnowski 1993, s. 11-14). Te bowiem sposoby wpływania na osobowość i zachowanie wychowanka posiadają znamiona zniewalania i urabiania, i nawet jeśli przynoszą określone efekty, to nie jestem pewna, czy o takie właśnie rezultaty powinno chodzić wychowawcy. Janusz Korczak przestrzega przed podobnym wychowaniem, przypominając „(...) że wszystko, co osiągnięte tresurą, naciskiem, przemocą jest nietrwałe, niepewne, zawodne” (Korczak 1992, s. 49). Mądrym wychowawcą będzie ten, „który nie wtłacza, a wyzwala, nie ciągnie, a wznosi, nie dyktuje, a uczy, nie żąda, a zapytuje” (Korczak 1992, s. 82).

Czym zatem jest wychowanie? Bliskie jest mi w odpowiedzi na to pytanie stanowisko prezentowane przez Jana Pawła II, dla którego „wychowanie jest stawaniem się człowieka coraz bardziej człowiekiem, czyli troską o to, ażeby bardziej «był», a nie tylko więcej «miał». Bardziej i pełniej być człowiekiem, to znaczy umieć «być» nie tylko «z drugim», ale także «dla drugich»" (za: Bilicki 20oo, s. 61). W ten sposób, w procesie wychowania ma miejsce wzajemne obdarzanie się człowieczeństwem. 
Rodzice obdarzają nim dziecko, ale i sami tego doświadczają od dziecka (Jan Paweł II 1994). Obdarzanie drugiej, a szczególnie młodej osoby, człowieczeństwem, jest wielkim darem ofiarowanym jej i dla niej. Takie wychowanie jest właśnie dorastaniem do pełni człowieczeństwa. Podobnie powinno wyglądać wychowanie podejmowane przez inne, wspierające rodzinę w tym niezwykle ważnym zadaniu, środowiska, a więc szkołę, Kościół czy państwo.

Stawanie się człowiekiem to nabywanie cech ludzkich, a te mogą się wyłącznie ujawniać w obliczu podejmowanych wyborów i decyzji, dla których punktem wyjścia zawsze są poznane w procesie wychowania i uznane wartości moralne. Ale nie można tych wartości uznać dopóty, dopóki nie zrozumie się ich znaczenia dla porządkowania ludzkiego życia i nadawania mu sensu. Wychowanie ma zatem za zadanie rozbudzać wychowanka i przy jego świadomym, aktywnym udziale i z pomocą wychowawcy wprowadzać go w wartościowe życie, uczyć i zachęcać do życia mocno osadzonego w wyznawanym systemie wartości. Wychowanie zatem jest stworzeniem takiej okoliczności - jak powiada Maurice Debesse - która „nie tworzy człowieka, ale pomaga mu tworzyć samego siebie” (Debesse 1996, s. 122).

\section{„Złe” wychowanie}

Zaprezentowane powyżej rozważania, dotyczące tego, czym jest wychowanie, skłaniają do poszukiwania odpowiedzi na następujące pytania: Czy wychowanie może być złe? Czy jeśli obserwujemy u człowieka zaburzenia w jego rozwoju i funkcjonowaniu albo też zachowaniu, które nie powinny i nie mogą być akceptowane przez innych, to możemy powiedzieć, że są one rezultatem „złego” wychowania? Czy jest to raczej efekt błędów popełnianych podczas organizowania doświadczeń dziecka albo rodzaj zaniechania w dostarczaniu mu takich bodźców, które byłyby wsparciem dla jego wychowania, czyli - jak uważał Klaus Schaller - stanowiły pomoc dla istoty ludzkiej w odnajdywaniu się w swoim człowieczeństwie (za: Buczek 2013).

Z określeniem „złe wychowanie” spotykamy się w takim przypadku, kiedy ktoś dokonuje oceny czyjegoś obserwowanego, a nieakceptowanego zachowania. Można wtedy np. usłyszeć: „to, co robisz, świadczy o tym, że jesteś źle wychowany” albo: „rodzice, nauczyciele źle cię wychowali”. W taki sposób wyrażona ocena czyjegoś zachowania rzeczywiście sugeruje, że wychowanie może być również złe.

Zastanówmy się zatem, czy powinno się mówić, że ktoś jest „źle wychowany”? Jeśli wychowanek zachowuje się w sposób niewłaściwy, narusza i pogwałca podstawowe wartości, to należałoby się raczej zastanowić, czy aby nie zabrakło mu wychowania, czy nie został go z jakiś powodów pozbawiony, a więc, czy aby nie została zerwana ta niezbędna dla dobrego wychowania jego więź z wychowawcą? Wychowanie bowiem nigdy nie powinno być złe, wychowując dziecko nie powinno się odmawiać mu prawa do wniknięcia w życie wartościowe. Trudno jest nazywać wychowawcą tego, kto przed dzieckiem wartości nie odkrywa, kto 
hamuje lub uniemożliwia mu pełny, harmonijny rozwój. Nie powinien nazywać siebie wychowawcą ten, kto dziecka nie kocha. Bo ten, kto kocha, jest właśnie wychowawcą - wrażliwym i oddanym, gotowym wspierać i wyzwalać w dziecku pokłady dobra.

Jeszcze w jednym przypadku można zetknąć się z określeniem „złe wychowanie”. Tak właśnie zatytułował jeden ze swoich filmów z 2004 roku hiszpański reżyser i scenarzysta Pedro Almodovar. Fabuła filmu koncentruje uwagę widza wokół problemu molestowania seksualnego młodych chłopców przez katolickiego księdza. Tytuł filmu i jego treść sugerują zatem widzowi, że molestowanie seksualne nieletnich jest przejawem wychowania, tyle tylko, że ocenianego jako złe. Nie zgadzam się z nazywaniem krzywdzących zachowań wobec dzieci czy kogokolwiek innego - wychowaniem, nawet wówczas, gdy dodaje się do tego określenia przymiotnik „złe”. W moim przekonaniu ten film pokazuje i zwraca uwagę widza na tzw. „zły dotyk", jak przyjęło się nazywać wszelkie akty seksualnego wykorzystywania nieletnich - zresztą zabronione i surowo karane. Zatem to nie jest obraz prezentujący „złe” wychowanie, ale przykład złego, krzywdzącego zachowania dorosłego wobec dziecka, którego on po prostu nie potrafi obdarzyć należną mu miłością. Kochający wychowawca nie powinien bowiem wyrządzać dziecku krzywdy ani też pozwalać sobie na wykorzystanie jego zaufania i oddania, sprzeniewierzać się jego wierze w szlachetne zamiary wychowawcy.

Zaprezentowane powyżej przesłanki, które ukazują szczególną rolę wychowawcy i określają jednoznacznie warunki korzystne dla wychowania, nie pozwalają na przyjęcie stanowiska, jakie miałoby wskazywać, iż wychowanie może być albo „dobre”, albo „złe”. Istnieje, owszem, taka możliwość, że wychowanek nie zetknie się ze wspierającą go dłonią wychowawcy, w wyniku czego może pobłądzić, sprawiać trudności wychowawcze, a nawet wejść na drogę przestępstwa, ale w moim przekonaniu nie powinno się tego przypadku traktować jako efektu „złego” wychowania. Jest on raczej rezultatem braku wychowania lub zaniedbywania ważnego obowiązku, jaki powierzono dorosłym. Dzieci trudne, a z czasem także popadające w konflikty z samymi sobą i innymi dorosłymi są osobami, którym - z jakiś powodów - wychowania zabrakło. Wychowawcy nie wypełnili wobec nich swojej powinności, nie obdarzyli ich potrzebną do wzrostu i dojrzewania miłością, nie miały one możliwości zetknąć się z wartościowym życiem i nie nauczyły się tego, jak uczynić swoje życie wartościowym.

Potwierdzają to m.in. badania nad życiorysami dzieci i młodzieży sprawiającymi trudności wychowawcze, są one społecznie nieprzystosowane albo ulegają różnorakim uzależnieniom. Są to młodzi ludzie - jak zauważa A. Szlazakowa - którym „w pewnym okresie życia zabrakło miłości w rodzinie, które zostały odtrącone. Gdy jednocześnie nie znalazły życzliwości i autorytetu innej osoby dorosłej - uległy wpływowi zdegenerowanej grupy ze środowiska rówieśniczego" (Szlązakowa 1989, s. 159). Są to zatem ci młodzi, którzy nie tyle zostali „źle” wychowani, ale po prostu odmówiono im prawa do wychowania. 


\section{Konstatacje końcowe}

Rzeczywistości dobra i zła, prawdy i kłamstwa, piękna i brzydoty, ciemności i światła od zawsze istniały obok siebie. Żyjąc, człowiek ma możliwość i powinien uczyć się rozpoznawać i oceniać te rzeczywistości, chcieć wnikać nie w to, co złe, ale właśnie potęgować dobro, prawdę i piękno. Jednak bez starannie i odpowiedzialnie przeprowadzonego procesu wychowania będzie to trudne, a może nawet niemożliwe. Odpowiednie wychowanie jest dzisiaj szczególnie potrzebne, w świecie, który dotyka tak mocno zobojętnienie na wartości i dobro człowieka. Tymczasem obserwujemy, paradoksalnie, raczej redukowanie funkcji wychowawczej w środowiskach, które w największym stopniu powinny być w ten proces zaangażowane, tj. w rodzinie i szkole. A wobec tak „trudnego świata”, w którym przyszło żyć współczesnym ludziom, dzieciom i młodzieży, „obniżania się jakości życia, upadku kultury i występowania zjawisk patologicznych (narkomania, przemoc, agresja) (...)" (Bereźnicki 2015, s. 29) przyczynia się to do poważnego zaniedbania roli dorosłych wobec młodych i może być uznane za przejaw ignorancji. „System wartości będący podstawą wychowania - powiada F. Bereźnicki - wymaga poważnej refleksji, gdyż edukację trawi erozja moralna, a bez odpowiedniego wychowania młodzieży nie jest możliwa odnowa moralna naszego społeczeństwa” (Bereźnicki 2015, s. 29). Potrzebujemy dzisiaj edukacji, która będzie ukierunkowana na wartości.

W procesie wychowania wychowanek zostaje powierzony wychowawcy, w nadziei, że otrzyma od niego to, co dobrze ukierunkuje i wspomoże jego dorastanie. Wychowanie jest zatem dobrem, którym wrażliwi i odpowiedzialni dorośli mogą obdarować młodych. Nigdy nie powinno być złe, jeśli rzeczywiście ma być wychowaniem. Wychowawca może popełnić błąd, może zaniechać czynności wychowawczych i przez to nie osiągnąć zamierzonego efektu. J. Korczak przestrzega: „Jeśli rodzina (szkoła i każde inne środowisko wychowania - przyp. aut.) nie umie lub nie chce ująć steru wychowania w swe ręce, dusza dziecka oddana jest na łaskę losu" (Korczak 1998, s. 151). Mowa jest wtedy o takim dziecku, któremu „odmówiono” prawa do wychowania.

Wychowawca może i ma prawo się mylić. Ale nie jest wychowawcą ten, kto nie kieruje się $\mathrm{w}$ swoim postępowaniu $\mathrm{z}$ wychowankiem intencją czynienia wobec niego dobra, dyktowanego miłością do dziecka. Nie powinno się zatem nazywać wychowaniem takiej interakcji z wychowankiem, w której zabrakło wyrażania i doświadczania miłości, zaufania, akceptacji (bez względu na to, jakie dziecko jest), zrozumienia i bycia ze sobą. To prawda, że wówczas dzieci nabywają złych nawyków i zachowań, a ich rozwój nie przebiega właściwie. Ale bynajmniej nie nazywałabym takiej okoliczności, która sprzyja kształtowaniu się niewłaściwych postaw „wychowaniem złym”, a raczej skłonna jestem nazywać ją po prostu sytuacją, w której wychowanie nie zaistniało, zabrakło go.

Do bycia wychowawcą należałoby się dobrze przygotować, przez ustawiczny namysł nad rolą, jaką się odgrywa w wychowaniu dzieci i młodzieży, nad 
odpowiedzialnością za nich i znaczeniem własnej wobec nich postawy. Podobnie bowiem, jak pod troskliwą opieką wychowawcy wzrasta dziecko, tak i wychowawca stale powinien dojrzewać do bycia dla dziecka przewodnikiem po świecie wartości, wrażliwym i oddanym dziecku. Dobry wychowawca chce dziecko poznawać, szanować je, uznawać należne istocie ludzkiej prawo do godności. Chce pozostawać $\mathrm{z}$ nim $\mathrm{w}$ dialogu.

Wychowanek potrzebuje ofiarowanego mu przez wychowawcę czasu - na dialog, który potwierdza, że jest dla dorosłego kimś ważnym, gdyż w dialogu wychowawca rozmawia $\mathrm{z}$ wychowankiem, a nie tylko mówi do niego. Jest gotowy, aby go słuchać, bardziej poznawać, rozumieć. Taki klimat sprzyja budowaniu podmiotowej relacji wychowawczej, pomaga dziecku stawać się bardziej samodzielnym, odpowiedzialnym i niezależnym.

Wychowanie pełne staranności jest dzisiaj młodym szczególnie potrzebne. Należy się zgodzić z takim twierdzeniem, szczególnie wówczas, gdy uświadomimy sobie, jak wiele zagrożeń dla harmonijnego rozwoju dzieci i młodzieży czyha na nie w świecie, w którym przyszło im dorastać. Aby to lepiej zrozumieć, może trzeba znowu, z uwagą, wczytać się w słowa zaniepokojonego o stan wychowania w polskiej rodzinie i szkole Bogdana Suchodolskiego, który w taki oto sposób wypowiedział się o wychowaniu w końcu XX wieku: „Nie jesteśmy wprawdzie społeczeństwem bez szkół - co obiecywał kiedyś I. Illich - ale jesteśmy już społeczeństwem bez szkół wychowujących, a może nawet społeczeństwem bez wychowania prawdziwego w ogóle" (Suchodolski 1983, s. 11).

Czy nie jest właśnie tak, że także dzisiaj, nie tylko w szkole, ale i w wielu rodzinach zaniedbuje się wychowanie dziecii A przecież wciąż potrzebujemy prawdziwego wychowania, które będzie „krzewić nadzieję, iż za sprawą ludzi - może za sprawą młodych pokoleń - potrafimy na tym globie stworzyć życie godne i szczęśliwe dla wszystkich jego mieszkańców" (Suchodolski 1983, s. 3).

Co możemy zrobić, aby wychowaniu nadać dzisiaj właściwe znaczenie i przywrócić mu należną pozycję w procesie edukacji młodego pokolenia? Wydaje się, że dobrym kierunkiem w procesie edukacji byłoby przeorientowanie pozycji poszczególnych jej celów, tj. dydaktycznych, kształcących i wychowawczych. O ile do osiągania celów dydaktycznych i kształcących przykłada się wiele starania i w szkole, i w rodzinie, o tyle trzeba przyznać, że na realizację celów wychowawczych albo już brakuje czasu, albo się je po prostu marginalizuje. Podzielam w tym przypadku pogląd F. Bereźnickiego, który wyraża propozycję nowego ujęcia celów współczesnej edukacji, edukacji dla potrzeb „jutra”, w następujący sposób: „rozwój osobowości, kształtowanie postaw wobec świata wartości, światopoglądu, przygotowanie do samorozwoju - wyposażenie w sprawności i wiadomości" (Bereźnicki 2015, s. 31).

Taki układ celów edukacji jest nadzieją na przywrócenie w niej ładu i nadanie jej aksjologicznego znaczenia. Aby jednak tak było, potrzebujemy zaangażowanych, wrażliwych na los dzieci, odpowiedzialnych rodziców i wychowawców, którzy $\mathrm{z}$ należytą atencją będą traktowali powierzoną im funkcję. 


\section{Bibliografia}

Apel Twojego dziecka, dostępny na: http://fdn.pl/ulotka-apel-twojego-dziecka?cat1=77 $2 \&$ cat $2=663 \&$ cat $3=742$ (otwarty: 01.02.2017).

Bereźnicki F. (2015). Dydaktyka szkolna dla kandydatów na nauczycieli. Kraków: Oficyna Wydawnicza „Impuls”.

Bilicki T. (2000). Dziecko i wychowanie w pedagogii Jana Pawła II. Kraków: Oficyna Wydawnicza „Impuls”.

Brejnak W. (1993). Kocham i wychowuję. Poradnik dla rodziców i nauczycieli. Warszawa: Oficyna Wydawniczo-Poligraficzna i Reklamowo-Handlowa „Adam”.

Buczek W. (2013). Wychowanie dialogowe dzieci i młodzieży. „Pedagogika Personalno-Egzystencjalna”. dostępny na: http://www.pedagogika-dialogu.pl/ wychowanie-dialogowe-dzieci-i-mlodziezy (otwarty: 04.02.2017).

Cian L. (1991). Wychowanie w duchu księdza Bosko. Warszawa: Wydawnictwo Salezjańskie.

Debesse M. (1996). Etapy wychowania. Warszawa: Wydawnictwo Akademickie "Żak”.

Gurycka A. (1990). Błąd w wychowaniu. Warszawa: Wydawnictwa Szkolne i Pedagogiczne.

Jan Paweł II (1994). List do rodzin, dostępny na: http://www.opoka.org.pl/biblioteka/W/ WP/jan_pawel_ii/listy/gratissimam.html (otwarty: 03.03.2017).

Korczak J. (1992). Jak kochać dziecko. Warszawa: Jacek Santorski \& CO Agencja Wydawnicza.

Korczak J. (1998). Dzieła. Szkoła życia. Obrazki szpitalne. Artykuły pedagogiczne i medyczne (1900-1912). T. 4. Warszawa: Oficyna Wydawnicza Latonia.

Łobocki M. (2004). Teoria wychowania w zarysie. Kraków: „Impuls”.

Łopatkowa M. (1992). Pedagogika serca. Warszawa: Wydawnictwa Szkolne i Pedagogiczne.

Schwengeler B i Y. (1990). Wychowanie - udręka czy przyjemność? Poznań: Wydawnictwo Ewangeliczne.

Suchodolski B. (1983). Wychowanie pozbawione nadziei. „Kwartalnik Pedagogiczny”, nr 2, s. 3-12.

Szlązakowa A. (1989). Korczakowska postawa wobec dziecka. „Wychowanie Fizyczne i Zdrowotne", $\mathrm{nr}$ 4, s. 156-159.

Tarnowski J. (1990). Janusz Korczak dzisiaj. Warszawa: Akademia Teologii Katolickiej.

Tarnowski J. (1993). Jak wychowywać? Warszawa: Wydawnictwa Akademii Teologii Katolickiej.

Zarzecki L. (2012). Teoretyczne podstawy wychowania. Teoria i praktyka w zarysie. Jelenia Góra: Wydawnictwo Karkonoska Państwowa Szkoła Wyższa. 


\title{
REFLECTIONS ON A “GOOD” AND “BAD” UPBRINGING
}

\begin{abstract}
In this paper the author presented issues regarding the essence and objectives of contemporary upbringing. She treats upbringing as a duty of adults towards young people, and a task that should never be neglected. The author attempts to justify the idea that upbringing should never be "bad". In the author's opinion, only behaviours and attitudes (also adult attitudes towards the young) may be inappropriate, but the upbringing, in which educators ought to be guided by the intention of doing good and passing it on to the child, should be good. In view of the literature presented and own reflections the author tries to discuss and justify the above thesis.
\end{abstract}

Keywords: upbringing, child, educator, parents, values, upbringing relationship.

Jolanta Derbich - doktor nauk o kulturze fizycznej, zatrudniona na stanowisku starszego wykładowcy w Zakładzie Pedagogiki i Psychologii na Wydziale Wychowania Fizycznego Akademii Wychowania Fizycznego Józefa Piłsudskiego w Warszawie. Autorka wielu publikacji, w tym artykułów i rozdziałów w monografiach i podręcznikach. Zainteresowania badawcze: pedagogika, pedagogika kultury fizycznej, edukacja zdrowotna i promocja zdrowia. Adres e-mailowy: jolanta.derbich@awf.edu.pl. 